\title{
Erratum to: Heavy metals assessment and identification of their sources in agricultural soils of Southern Tehran, Iran
}

\author{
Abbas Hani • Ebrahim Pazira
}

Published online: 3 September 2010

(C) Springer Science+Business Media B.V. 2010

\section{Erratum to: Environ Monit Assess \\ DOI 10.1007/s10661-010-1612-3}

The original version of this article unfortunately contained incorrect author affiliation. The correct information is as follows.
A. Hani
Department of Agriculture, Islamic Azad Univer- sity, Saveh Branch, Saveh, Iran
e-mail: Abbas_hani@iau-saveh.ac.ir

The online version of the original article can be found at http://dx.doi.org/10.1007/s10661-010-1612-3.

\footnotetext{
A. Hani $(\varangle)$

Department of Agriculture, Islamic Azad University, Saveh Branch, Saveh, Iran

e-mail: Abbas_hani@iau-saveh.ac.ir

E. Pazira

Head Soil Science Department, Faculty of Agriculture and Natural Resources, Science and Research Branch, Islamic Azad University, P.O. Box 14515/775,

Tehran, Iran

e-mail: Ebrahimpazira@yahoo.com
} 